\title{
An Overview of Current Challenges in New Food Product Development
}

\author{
Lucia Azanedo ${ }^{1,2}$, Guillermo Garcia-Garcia ${ }^{1,3}$, Jamie Stone ${ }^{1}$ and Shahin Rahimifard ${ }^{1, *}$ \\ 1 Centre for Sustainable Manufacturing and Recycling Technologies (SMART), Loughborough University, \\ Loughborough LE11 3TU, UK; G.Garcia-Garcia@sheffield.ac.uk \\ 2 R\&D Department, Frit Ravich S.L., Cl. Riudellots, s/n, Polígono Industrial Puigtió, Maçanet de la Selva, \\ 17412 Girona, Spain \\ 3 Department of Chemical and Biological Engineering, The University of Sheffield, Sheffield S10 2TN, UK \\ * Correspondence: S.Rahimifard@lboro.ac.uk
}

Received: 3 April 2020; Accepted: 20 April 2020; Published: 21 April 2020

\begin{abstract}
New product development (NPD) is essential for business success and growth. High- to medium-technology manufacturing sectors have introduced standard models. The adaptation of these systematic NPD procedures supported by appropriate decision support tools has provided significant benefits in production cost, product quality and supply chain availability. However, the challenges involved in NPD of food are rapidly increasing due to consumer demand for organic and healthy diets, in particular, more nutritious low-calorie food, and preference for customised and personalised food products. This has resulted in a proliferation of new varieties, types and shapes of food products that are constantly introduced. Most of these new products are developed based on company-specific ad hoc NPD procedures, within small to medium enterprises that form the biggest proportion of food producers in most developed countries. This highlights a need for further research into novel NPD methods and tools in the food sector. This communication provides an overview of the NPD processes, analyses their strengths and shortcomings and outlines critical missing capabilities for food manufacturers in specific.
\end{abstract}

Keywords: new product development; sustainability; food manufacturing; lifecycle management

Whilst the food industry is usually associated with low research intensity and poor technology adaptation, several emerging trends may change this, including increasing consumer demand for fresh vegetables and fruits, organic products, greater traceability information and a desire to reduce meat consumption and improve animal welfare [1]. Meeting these requirements will require more than simply increasing supply-it will require innovation in the forms that these foods are supplied to ensure that today's consumers have the broadest possible range of flavours, colours and nutritional value. Innovation is driven by fierce competition between large retailers that, in turn, is passed onto their manufacturers, resulting in, for example, more effective food packaging to increase product shelf life and minimise waste, use of alternative protein sources and product reformulation based on seasonal and locally available ingredients.

New product development (NPD) is the process of designing a new product, producing it and bringing it to market. Most new food products, particularly those produced by small- and medium-sized enterprises, are developed based on company-specific NPD procedures or models adapted from other sectors [2-4]. Little standardisation exists, which is a major problem because in food production factors such as consumer health, availability and access to ingredients, resilience of food supply chains, sustainability of ingredients and, more generally, management of the food product's lifecycle must be taken into account consistently. An opportunity exists for a formalised, specific-food-sector NPD process. To be able to envision what such a process would look like, one must 
first understand the strengths and shortcomings of the most common NPD models and explore how they have been adopted. One must then consider the unique challenges of the food-manufacturing sector. This short communication aims to provide an overview of the NPD process, discuss its importance in the food sector, show examples of NPD processes in food manufacturing, highlight their shortcomings and describe key aspects that should be considered in NPD of food products.

New product development has been defined as the process of transforming a new market opportunity into a commercial product through a sequence of activities, with the purpose of achieving specific targets [5-7]. Because the success of a new product depends on many variables, developing new products can be a complex and risky business activity, yet vital for product market growth and gaining competitive advantage [8]. NPD is of particular importance in the food sector, since food products that successfully enter the food market significantly increase the value, and therefore the price, of their ingredients. For many processed food products, the economic value of food ingredients at the farm gate only makes up 20 percent of the economic value of the final processed food product on the supermarket shelf. This means that food recipes and processing, defined in the NPD process, are key to maximising the economic value of food products. To adopt an effective NPD process, three types of knowledge are essential. The first is understanding of internal strengths and weaknesses, brand portfolio, company strategy, competitors, distribution channels and the wider market environment [9]. The second is knowledge of the technologies needed to produce the product. Finally, knowledge of current consumer needs and how they may react to emerging societal trends, as well as understanding of latent needs, which are not yet fulfilled by current offerings, is vital.

To be successful, NPD needs to be completely integrated across a company, from managers to production line operators [10]. In an efficient NPD process, all actors must not only know their specific tasks in the project, but also the likely upstream and downstream implications, such as possible responses from competitors and ramifications for raw material availability, with a lifecycle view.

Food manufacturing companies use different approaches, methods and strategies to develop new products. For example, manufacturers of convenience products tend to follow Stage-Gate [11,12] or milestone-based models [13], which typically consist of an idea-scoping stage followed by business case development, product testing, evaluation and launch. Other models take a more holistic and often circular approach. For example, Rozenfeld and his colleagues developed the "PD Process Unified Model", which considers the NPD process as a holistic process that integrates marketing and engineering in three stages [14]. Pre-development, the first stage, entails assessment of market needs, internal capabilities, potential products that could match these and, finally, associated business models. Development, the second stage, consists of prototype development, testing and refinement. Post-development, the third stage, comprises launch, product performance in the market and feedback into subsequent NPD.

Different NPD models used are based primarily on various stages clustered around the pre-development, development and post-development phases presented above. None of these models was developed specifically for the food sector, which has unique attributes. For instance, ingredients used in food manufacturing are perishable and must be stored under specific conditions before consumption. Additionally, even after a new food product has been designed and produced, food manufacturers struggle from continuous changes in their manufacturing operations-for example, sourcing of ingredients, new requirements to improve food safety and shelf life stability. Furthermore, because NPD models were not designed for food manufacturing specifically, food manufacturers may not have predictable product turnaround and stable supply chains. For new food product development (NFPD), NPD models require modifications to better serve the food industry. The following key areas should be included:

- Meeting consumer demands and sensory attributes: Contemporary consumer demands place a premium on minimal preparation time as well as seasonal colours and palatable textures. 
- Seasonality of ingredients: Consumers value seasonal foods because of their perception of quality and local sourcing. Overreliance on in-season ingredients can be risky due to their limited availability at certain times of the year.

- Sourcing and distribution of local ingredients: There are many potential benefits to be gained from supporting local networks rather than relying on international supply chains. Environmental benefits may include reduced emissions associated with transport. Consumption of local products can contribute to local job creation and reduced transportation costs. Finally, local sourcing of ingredients can help to diversify the food system, making it more resilient to disruptions in certain areas of production and potentially expand the range of ingredients and thereby the nutritional diversity available to consumers.

- Food safety: Food safety is one of the most important issues food manufacturers face. Food developers must have knowledge about the quality and storage requirements of raw materials and final products, product, formulation and the processes needed to safely manufacture the final food product. Consequently, food manufacturers play a pivotal role assuring product safety and identifying possible hazards from the beginning of the NFPD process.

- Traceability of ingredients and final products: Food products and food supply chains have significantly changed over the last century, from production of localised and seasonal ingredients to production of complex food products with a high variety of ingredients from many different regions of the world. Technology development has more recently allowed information about a food product's ingredients in all stages of the food supply chain to be stored and shared, improving traceability. Large companies such a Nestle and Walmart have implemented internal and supplier traceability as part of their quality control system, and there are signs that most large retailers and manufacturers in developed societies are following suit.

- Manufacturing food products at a large scale: Scaling up food recipes developed by the NFPD team to an industrial scale requires several actions, such as adjustment of process times and temperatures, consideration of hygiene conditions in the manufacturing plant, determination of logistics plans, including storage, considering the traits of the food product and selection of equipment and their working conditions.

- Environmental impact: Food products create a significant impact environmental impact over their lifecycle. Food consumption contributes between 15 percent and 28 percent to the total emissions of developed countries [15] and around 30 percent of the total energy consumption worldwide [16]. NFPD can support mitigating these environmental impacts, since it is estimated that around 80 percent of the environmental impact of a product is determined at the design phase $[17,18]$.

The food-manufacturing sector has adapted various generic NPD models to suit its needs over the years with great success. However, changing consumer requirements, intense retailer pressure and growing pressure around the need to minimise negative environmental impacts mean that existing models need overhauling. Factors such as closely meeting consumer demands, using seasonal and local ingredients, ensuring food safety and traceability, ensuring production at scale and minimising lifecycle environmental impacts must be included in any formalised NPD model specifically designed for food manufacturers.

Author Contributions: Conceptualisation, L.A., G.G.-G., J.S. and S.R.; methodology, L.A., G.G.-G. and J.S.; formal analysis, L.A., G.G.-G. and J.S.; resources, S.R.; writing-original draft preparation, L.A., G.G.-G. and J.S.; writing - review and editing, G.G.-G. and J.S.; supervision, S.R.; project administration, S.R.; funding acquisition, S.R. All authors have read and agreed to the published version of the manuscript.

Funding: This research was funded by the Engineering and Physical Sciences Research Council (EPSRC) UK, grant number EP/K030957/1. The APC was funded by Loughborough University.

Conflicts of Interest: The authors declare no conflict of interest. The funders had no role in the design of the study; in the collection, analyses, or interpretation of data; in the writing of the manuscript, or in the decision to publish the results. 


\section{References}

1. Santeramo, F.G.; Carlucci, D.; De Devitiis, B.; Seccia, A.; Stasi, A.; Viscecchia, R.; Nardone, G. Emerging trends in European food, diets and food industry. Food Res. Int. 2018, 104, 39-47. [CrossRef] [PubMed]

2. Pinna, C.; Galati, F.; Rossi, M.; Saidy, C.; Harik, R.; Terzi, S. Effect of product lifecycle management on new product development performances: Evidence from the food industry. Comput. Ind. 2018, 100, 184-195. [CrossRef]

3. Rossetti, G.; Giraudo, F.; Murer, P.; Arcusin, L. Comparative Analysis of Product Development Process Management Models. Am. J. Ind. Eng. 2014, 2, 5-9.

4. Rudolph, M.J. The food product development process. Br. Food J. 1995, 97, 3-11. [CrossRef]

5. Ulrich, K.T.; Eppinger, S.D. Product Design and Development; McGraw-Hill Education: New York, NY, USA, 2016.

6. Rudder, A.; Ainsworth, P.; Holgate, D. New food product development: Strategies for success? Br. Food J. 2001, 103, 657-671. [CrossRef]

7. Krishnan, V.; Ulrich, K.T. Product Development Decisions: A Review of the Literature. Manag. Sci. 2001, 47, 1-21. [CrossRef]

8. Gao, J.; Bernard, A. An overview of knowledge sharing in new product development. Int. J. Adv. Manuf. Technol. 2017, 94, 1545-1550. [CrossRef]

9. Acur, N.; Kandemir, D.; Boer, H. Strategic alignment and new product development: Drivers and performance effects. J. Prod. Innov. Manag. 2012, 29, 304-318. [CrossRef]

10. Felekoglu, B.; Maier, A.M.; Moultrie, J. Interactions in new product development: How the nature of the NPD process influences interaction between teams and management. J. Eng. Technol. Manag. 2013, 30, 384-401. [CrossRef]

11. Davis, D.; Chelliah, J.; Minter, S. New Product Development Processes in The Australian FMCG Industry. Contemp. Manag. Res. 2014, 10, 3-22. [CrossRef]

12. Grönlund, J.; Sjödin, D.R.; Frishammar, J. Open Innovation and the Stage-Gate Process: A Revised Model for New Product Development. Calif. Manag. Rev. 2010, 52, 106-131. [CrossRef]

13. Cooper, R.G.; Sommer, A.F. Agile-Stage-Gate for Manufacturers. Res. Technol. Manag. 2018, 61, 17-26. [CrossRef]

14. Rozenfeld, H.; Forcellini, F.A.; Amaral, D.C. Gestão de Desenvolvimento de Produtos: Uma Referência para a Melhoria do Processo; Saraiva, Ed.; Saraiva: Sao Paulo, Brazil, 2006.

15. Garnett, T. Where are the best opportunities for reducing greenhouse gas emissions in the food system (including the food chain)? Food Policy 2011, 36, S23-S32. [CrossRef]

16. The Lancet Planetary Health Sustainable food for a sustainable planet. Lancet Planet. Health 2017, 1, e123. [CrossRef]

17. DG Enterprise \& Industry and DG Energy_European Commission Ecodesign-Your Future. How Ecodesign Can Help the Environment by Making Products Smarter; Publications Office of the European Union: Luxembourg, 2014.

18. McAloone, T.C.; Bey, N. Environmental Improvement through Product Development: A Guide; Danish Environmental Protection Agency: Copenhagen, Denmark, 2009.

(C) 2020 by the authors. Licensee MDPI, Basel, Switzerland. This article is an open access article distributed under the terms and conditions of the Creative Commons Attribution (CC BY) license (http://creativecommons.org/licenses/by/4.0/). 